\title{
Pensar los saberes ligados a nuestra práctica docente
}

\author{
Pilar Chois ${ }^{1}$
}

La contratación de profesores universitarios suele estar sustentada en su especialidad disciplinar y su trayectoria investigativa, pues usualmente se considera que la práctica docente en la educación superior se reduce a técnicas para transmitir información (1). Por ello, no siempre los directivos consideran indispensable que quienes aspiran a ser docentes en las instituciones que dirigen cuenten con formación en didáctica $o$ pedagogía, ni que tengan experiencia de ese tipopara poder orientar cursos en este nivel.

En consecuencia, es usual que algunas formas de ejercer la ensenanza se "hereden" casi de manera inconsciente de la observación de sus propios profesores durante su época de aprendices, lo cual puede incluir el seguimiento de modelos valorados positivamente, tanto por la institución como por los aprendices, como otros que no lo son. Sin embargo, no toda príctica docente se explica por la continuidad histórica, pues en ella se tejen las particularidades de los sujetos -sus saberes, emociones e intereses- $y$ de las instituciones -su proyecto educativo, las prácticas que promueve explícita o tácitamente-

La respuesta a asuntos como qué enseńar y de qué manera hacerlo, supone no solo la reproducción, sino la integración y generación de conocimiento por parte de quienes ejercen ese trabajo. No se trata necesariamente de un conocimiento sistematizado, sino de saberes de diversa procedencia que implican a veces ensayo y error, así como la construcción de soluciones a problemas que el trabajo mismo plantea, en las condiciones específicas en que se presenta. Esto se conocen en la literatura como

1 Editora asociada, Revista de la Facultad de Ciencias de la Salud de la Universidad del Cauca, Profesora Departamento de Fonoaudiología. Programa de Doctorado en Ciencias de la Educación, Universidad del Cauca, Popayán, Colombia. 
el pensamiento o conocimiento práctico del profesor $(2,3)$, un universo de saberes provenientes de la propia experiencia docente, un saber en uso.

La posibilidad de reflexionar sobre esos saberes y sobre la propia práctica docente en la que se gestan se constituye en una valiosa oportunidad para que los docentes universitarios consideremos posibles vías de cualificación.

La docencia universitaria en Ciencias de la Salud tiene, entre otras particularidades, la enorme responsabilidad de formar a quienes tendnán en sus manos, literalmente, la vida de las personas. En ese sentido, más allá de transmitir los conocimientos prácticos y declarativos de la profesión, el docente universitario en salud es responsable depensar si suspropiasprácticasde enseńanza y los saberes que allíseponen enjuego, son adecuados para que sus aprendices enfrenten desafios en sus propias trayectorias profesionales: ¿Genero oportunidades para que conozcan diversas alternativas profesionales y tomen decisiones informadas?, ¿Propongo dinámicas de interacción que permitan a mis estudiantes construir y sustentar sus propios puntos de vista al relacionarse con otros profesionales? ¿Cómo promuevo el aprender a buscar, seleccionar y discernir, en lugar del memorizar información que estaná obsoleta dentro de poco?

Bienvenidos los espaciospersonales e institucionales que nospermitan pensar en nuestros saberes para avanzar en nuestra formación como docentes universitarios en salud.

\section{REFERENCIAS}

1. Tovar-Gálvez J, García Contreras G. Investigación en la práctica docente universitaria: obstáculos epistemológicos y alternativas desde la Didáctica General Constructivista. Educaçăo e Pesquisa. 2012;38(4):881-896.

2. Gimeno Sacristán J, Pérez Gómez A. Comprender y transformar la enseńanza. 1996. Madrid: Ed. Morata.

3. Connelly F, Clandinin D. El método narrativo, la filosofía personal y las unidades narrativas en el estudio del enseńante. En Marcelo, El pensamiento del profesor (págs. 32-48). 1984. Barcelona: Ed. CEAC. 


\title{
Knowledge linked to our teaching practice
}

\author{
Pilar Chois ${ }^{1}$
}

The assignment of university professors is usually based on their disciplinary specialty and their research trajectory, since it is usually considered that the teaching practice-in higher education-is reduced to techniques for transmitting information (1). Therefore, managers do not always consider it essential that those who aspire to be teachers in the institutions they run have training in "teaching or pedagogy", or have such experience to guide courses at this level.

As a result, it is usual for some forms of teaching to "inherit" almost unconsciously from the observation of their own teachers during their own training, which may include the well-valued models, both by the institution and by the students. However, not all teaching practice is explained by the historical continuity.

The answer to these issues supposes not only the reproduction, but the integration and generation of knowledge from those who actively practice that work. It is not necessarily a systematized knowledge, but knowledge from different sources that sometimes involve trial and error, as well as the construction of solutions to problems that the work itself poses, in the specific conditions in which it is presented. This is known in the literature as the teacher's thinking or practical knowledge $(2,3)$, a universe of knowledge coming from the teaching experience itself, a knowledge in real use.

The possibility of reflecting on this knowledge and on the teaching practice in which it is set up constitutes a valuable opportunity for university teachers to consider possible means of qualification.

University teaching in Health Sciences has, among other peculiarities, the enormous responsibility of training those who will literally have the lives of people in their hands. In that sense, beyond transmitting the practical and declarative knowledge of the profession, the healthcare teacher is responsible for thinking whether their own teaching practices and the knowledge that is put into play there, are adequate for

1 Editora asociada, Revista de la Facultad de Ciencias de la Salud de la Universidad del Cauca, Profesora Departamento de Fonoaudiología. Programa de Doctorado en Ciencias de la Educación, Universidad del Cauca, Popayán, Colombia. 
their students to face challenges in their own professional careers: Do we generate opportunities for you to meet different professional alternatives and make informed decisions? Do we propose interaction dynamics that allow my students to build and sustain their own points of view when interacting with other professionals? How do we promote learning to search, select and discern, instead of memorizing information that will be obsolete shortly?

Welcome personal and institutional spaces that allow us to think in our knowledge to advance our training as university teachers in health.

\section{REFERENCES}

1. Tovar-Gálvez J, García Contreras G. Investigación en la práctica docente universitaria: obstáculos epistemológicos y alternativas desde la Didáctica General Constructivista. Educaçăo e Pesquisa. 2012;38(4):881-896.

2. Gimeno Sacristán J, Pérez Gómez A. Comprender y transformar la enseńanza. 1996. Madrid: Ed. Morata.

3. Connelly F, Clandinin D. El método narrativo, la filosofía personal y las unidades narrativas en el estudio del enseńante. En Marcelo, El pensamiento del profesor (págs. 32-48). 1984. Barcelona: Ed. CEAC. 